\title{
Sosyal Bilgiler Öğretmenlerinin Öğretim Yöntem ve Uygulamalarının Değerlendirilmesi
}

\author{
Erhan YAYLAK \\ Ordu Üniversitesi, Eğitim Fakültesi, Sosyal Bilgiler Eğitimi ABD, Ordu \\ erhanyaylak@gmail.com \\ ORCID ID: https://orcid.org/0000-0003-4612-3041
}

\begin{tabular}{lrr} 
Araştırma Makalesi & DOI: $10.31592 /$ aeusbed.621664 \\
\hline Geliş Tarihi: 18.09 .2019 & Revize Tarihi: 19.02 .2020 & Kabul Tarihi: 26.02 .2020
\end{tabular}

\section{Atıf Bilgisi}

Yaylak, E. (2020). Sosyal bilgiler öğretmenlerinin öğretim yöntem ve uygulamalarının değerlendirilmesi. Ahi Evran Üniversitesi Sosyal Bilimler Enstitüsü Dergisi, 6(1), 187-205.

\section{ÖZ}

Bu araştırmada; Türkiye'de Millî Eğitim Bakanlığına (MEB) bağlı devlet ve özel eğitim kurumlarında görev yapan Sosyal Bilgiler öğretmenlerinin (SBÖ) derslerinde tercih ettikleri öğretim yöntemlerini ve uygulamalarını belirlemek ve değerlendirmek amaçlanmıştır. Bu amaçla araştırmanın örneklemini, 20182019 eğitim-öğretim yılında Türkiye'nin çeşitli şehirlerinde görev yapan 631 SBÖ oluşturmaktadır. Araştırmada tarama (survey) yöntemi kullanılmıştır. Araştırmanın verileri "Kişisel Bilgi Formu" ve "Sosyal Bilgiler Öğretim Yöntem ve Uygulamaları” ölçeği ile toplanmıştır. SBÖ’nün tercih ettiği öğretim yöntem ve uygulamaları "pasif öğrenme yöntemleri", "öğrenen merkezli uygulamalar" ve "bilişsel strateji öğretimi" boyutları açısından incelenmiştir. Araştırmanın bulgularına göre; SBÖ’nün tercih ettiği öğretim yöntem ve uygulamaları ögrenim durumu, görev yapılan bölge, haftalık ders yükü ve mesleki kıdem değişkenlerine göre anlamlı farkl1lıklar göstermemekle birlikte; cinsiyet, mezun olunan fakülte, mezun olunan branş, görev yapılan okul türü değişkenlerine göre anlamlı farklılıklar göstermiştir. Araştırmadan elde edilen anlamlı farklılıklar şöyledir; SBÖ’ler, öğretim yöntem ve uygulamalarında en çok "pasif öğrenme yöntemlerini” kullanmaktadırlar. Kadın SBÖ’leri, "öğrenen merkezli uygulamalar” ve "bilişsel strateji öğretimi” gibi aktif öğrenme yöntemlerini erkek SBÖ’ye nazaran daha çok kullanmaktadırlar. Fen ve Edebiyat Fakültesi mezunu SBÖ’leri Eğitim Fakültesi mezunu SBÖ’lere göre aktif öğretim yöntemlerini daha çok kullanmaktadırlar. Özel eğitim kurumlarında görev yapan SBÖ devlet okullarında görev yapan SBÖ’ye nazaran aktif öğretim yöntemlerini daha çok kullanmaktadırlar.

Anahtar Kelimeler: Sosyal Bilgiler öğretmeni, Sosyal Bilgiler öğretimi, öğretim yöntem ve uygulamaları.

\section{Evaluation of Teaching Methods and Practices of Social Studies Teachers}

\begin{abstract}
The purpose of this research in Turkey in the Ministry of National Education (MEB), depending on the state and working in private educational institutions to determine their preferred teaching methods and practices, and to evaluate their courses in social studies teachers. The sample of the research for this purpose, constitutes the 2018-2019 academic year, serving in various cities of Turkey 631 social studies teacher. Survey method was used in the study. The data of the study were collected with the "Personal Information Form" and "Social Studies Teaching Methods and Practices" scale. The teaching methods and applications preferred by social studies teachers are examined in terms of the dimensions of "passive learning methods", "student-centered applications", and "cognitive strategy teaching." According to the findings of the study; Although the teaching methods and practices preferred by social studies teachers do not differ significantly according to educational status, duty area, weekly course load, and professional seniority variables; gender, graduated faculty, graduated branch, according to the types of school types of duty showed significant differences. The significant differences obtained from the study are as follows; social studies teachers use "passive learning methods" most in teaching methods and applications. Female social studies teachers use active learning methods such as "student-centered practices" and "cognitive strategy teaching" more than male social studies teachers. social studies teachers who are graduates of faculty of arts and science use active teaching methods more than social studies teachers. Social studies teachers working in private education institutions use active teaching methods more than social studies teachers working in public schools.
\end{abstract}

Keywords: Social studies teacher, Social studies teaching, teaching methods, and practices.

\section{Giriş}

Eğitim ve öğretim sistemleri, içinde bulunduğumuz bu çağa uygun nitelikte bireyler yetiştirebilmeyi amaçlamaktadır. Günümüz eğitim anlayışı öğrenenin bilgi düzeyinin değerlendirilmesinden ziyade, bilginin birey için anlamlı ve yaşantısal hâle getirilmesi esasına 
dayanmaktadır (Millî Eğitim Bakanlığı, 2017). Yeni öğretim programları, yapılandırmac1 (constructivist) olarak ifade edilen yaklaşımı da ön plana çıkarmaktadır. Yapılandırmacı yaklaşımda öğretmenlerin geleneksel olarak kullandığı yöntem ve tekniklerin dışında, öğretmenlerden öğrenen etkinlik merkezli yöntem ve teknikler kullanması beklenmektedir (Çelikkaya ve Kuş, 2009). Geleneksel öğretim yöntemlerin aksine yapılandırmacı öğretim yöntemleri ile yapılan öğretim öğrenenlerin bilgiyi daha etkin ve verimli bir şekilde işlemesine ve yeni fikirler ortaya çıkarmasına odaklanır (Sunal ve Haas, 2012). Böylece tartışan, sorgulayan, üreten, akıl yürüten, yeteneklerinin farkında olan, problem çözen ve eleştirel gözle bakabilen bireyleri yetiştirmek daha kolay olacaktır (Koç, 2013). Bu nedenle öğretmen kendisinin ve öğrenenlerinin gereksinim duyduğu bilginin ne olduğunu, nasıl ulaşılacağını ve nasıl kullanılacağını bilmeli ve öğrenenlere öğretmelidir (Adıgüzel, 2011).

Ülkelerin kalkınması ve bireylerin gelişimleri açısından büyük önem taşıyan eğitim-öğretim, pek çok unsurun sağlıklı bir şekilde bir arada bulunmasını gerektirmektedir. Öğrenen, öğretmen, yönetici, ders araç-gereçleri, eğitim-öğretim ortamı ve öğretim programı gibi unsurların bir arada uyumu eğitimin başarısını da etkilemektedir (Akçay, Akçay ve Kurt, 2016). Bir eğitim programının en önemli öğesi eğitim durumlarıdır ve öğrenme-öğretme etkinlikleri eğitim programının bu boyutunda gerçekleşmektedir (Demirel, 2007; Saracaloğlu, Yenice ve Gencel, 2011). Tan (2005) öğretim sürecinde farklı yöntem ve uygulamalar kullanımı ilgili olarak; "Öğrenme-öğretme sürecinde öğrenenlere istendik davranışların kazandırılmasına yönelik olarak yapılan tüm etkinlikler büyük bir titizlikle planlanmalı ve konunun öğretimi için en uygun öğretim etkinliklerine yer verilmelidir" şeklinde düşüncesini belirtmiştir. Ayrıca Davis Langston (2012), McCombs ve Miller (2007) da "Öğretim yöntem ve teknik tercihleri, öğretmenlerin eğitim felsefelerinin öğrenme-öğretme sürecine yansımaları olarak düşünülmektedir. Tercih edilen öğretim yöntem ve teknik bir anlamda öğretmenin ve eğitim sürecinin kalitesini belirlemektedir. $\mathrm{Bu}$ durum, eğitim programlarının verimliliğini ve öğrenenlerin performansını etkilediğini” ifade etmişlerdir.

Günümüzün çağdaş öğretmeni; "Öğretme-öğrenme süreçlerini iyi organize edebilen, öğrenenlerle etkileşim ve iletişim sağlayabilen, öğrenenlerin tepkilerini beden dillerinden yakalayabilen ve kendi beden dilini de kontrol altında tutabilen ve bunları bilinçli bir şekilde kullanma becerisine sahip bir uzman" olarak tanımlanmaktadır (Küçükoğlu ve Kaya, 2007). Öğrenme ve öğretme süreçlerinde öğretmeninin kullanacağı strateji, yöntem ve teknik hakkında bilgi sahibi olması gerekir. Öğretim yöntem ve teknikleri hakkında bilgi sahibi ve deneyimi olan öğretmenler derslerinde bunları kullanabilirler. Skutil, Haclickova ve Matejickova'ya (2016) göre bir öğretim yöntemi; "Bir öğretmenin ve bir öğrenenin çabalarını birleştiren ortak bir usul biçiminde, öğrenmeyi organize etmenin ve yönlendirmenin etkili bir yoludur. Bir öğretmenin yaratıcılığı ve kişisel gelişim seviyesi, bu öğretim yöntemlerinin nasıl kullanıldığını ve birleştirildiğini belirler” şeklinde açılamışlardır. Bu araştırmada bahsedilen öğretim yöntemleri; "Bir öğretmenin dersin anlaşılırlığını, eğitimsel çeşitliliğini ve belirli ders kazanımlarının karşılanması hedefine odaklanmayı gerçekleştirmek için kullandığ1 stratejilerdir" (Borich, 2011; Burke, 2012). Öğretim uygulamaları ise; "Öğrenenleri öğrenme durumlarıyla ilişkilendirmek için belirli içerik ve kavramların öğretimi esnasında seçilen ve uygulanan öğretim yöntem ve tekniklerini tanımlamak" için kullanılır (Marzano, Pickering ve Pollock, 2001).

National Council for the Social Studies (NCSS) yani ABD Sosyal Bilgiler Ulusal Konseyi "Bütün içerik alanlarında olduğu gibi Sosyal Bilgiler öğretiminde de tek bir yöntem, teknik ya da strateji kullanılmamalıdır. Çünkü Sosyal Bilgiler, vatandaşlık bilgisi, ekonomi, coğrafya ve tarih de dâhil olmak üzere pek çok disiplini içine alan ve demokratik bir toplumda vatandaşlık eğitimini temel alan çok boyutlu bir yapı durumundadır. Sosyal Bilgiler dersi ayrıca; matematik ve fen bilimleri gibi alanlar da bu içerik alanlarına önemli ölçüde katkılar sağladığını” belirterek Sosyal Bilgiler dersinde farklı yöntem ve uygulamaların kullanılması gerektiğini vurgulamıştır. Bu konu ile ilgili Gözütok (2006) ve Ocak (2007); "Eğitim ortamında kullanılan öğretim yöntem ve teknikler, hedeflerin gerçekleştirilmesinde ve eğitim durumlarının düzenlenmesinde önemli bir yere sahiptir. Öğretim yöntem ve teknikleri hakkında elde edilen bilgiler; amaca uygun yöntem/tekniğin seçimi, seçilen yöntem/tekniğin uygulanması, sınıf içinde etkili bir öğretimin yapılmasını etkiler." Silver ve Hanson 
(1996) ise; “Öğretme-öğrenme sürecinde öğretmen, giriş etkinlikleri ile öğreneni dersi öğrenmeye hazır hale getirdikten sonra, geliştirme aşamasında öğrenme etkinliklerini öğrenenlerin, zengin öğrenme yaşantıları geçirmelerine olanak sağlayacak şekilde düzenlenmeli, farklı öğrenme etkinliklerine yer vermeli ve başta öğretim teknolojileri olmak üzere tüm eğitim araç-gereçlerini etkin olarak kullanmalıdır" yorumlarında bulunmuşlardır. Savage ve Armstrong (1996) da "Kullanılacak öğretim yöntem ve tekniklerinin belirlenmesi etkili bir öğretimin oluşturulması bakımından önemlidir. Genellikle eğitim ortamında çeşitli yöntem ve teknikler bir arada kullanılır. Bu çeşitlilik, öğrenme ortamında bulunan öğrenenlerin ilgisini harekete geçirir. Öğretim yöntem ve teknikleri öğrenen özellikleri dikkate alınarak belirlenmeli; amaç ve içerikle de uyumlu olmasına özen gösterilmelidir" ifadesini kullanmıştır. Bu yüzden Millî Eğitim Bakanlığı (2005) da "öğrenme ve öğretme sürecinde öğrenenlerin kazandıkları bilgi ve becerileri yeniden yapılandırıp gerçek hayata aktarmalarını destekleyen yöntem ve tekniklerin kullanılmasını" önermiştir. Ayrıca Can, Yaşar ve Sözer, (1998) "Öğrenme-öğretme sürecinin başarılı olması için öğretmenlerin derste tercih ettikleri yöntem, teknik ve stratejilerin öneminin" yüksek olduğunu belirtmişlerdir.

Öğretmenlerin, öğretim elemanlarının ve öğretmen adaylarının tercih ettikleri/ kullandıkları öğretim yöntem, teknik ve stratejiler ile ilgili yapılan birçok araştırma bulunmaktadır. Öğretmenlerle yapılan araştırmalar çoğunluktadır. Bu araştırmalar; öğretim elemanlarının, öğretmenlerin ve öğretmen adaylarının tercih ettikleri veya kullandıkları öğretim yöntem ve uygulamalar olarak üç başlık altında incelenebilir. Bu araştırmalara göre; öğretmenler derslerinde daha çok soru-cevap tekniğini ve sunuş yoluyla öğrenme stratejisini kullanmaktadırlar (Akçay, Akçay ve Kurt, 2016; Aşılıoğlu, 2000; Avcı ve Kayabaş1, 2018; Aydemir, 2012; Aykaç, 2011; Binler, 2007; Bulut, 2010; Çelikkaya ve Kuş, 2009; Demirezen, 2001; Duman, 2008; Muşta ve Taşkaya, 2008; Sakallı, Hürsen ve Özçınar, 2007; Sarıaslan, 2005; Öztürk, 2004). Öğretim elemanlarının öğretim yöntem ve uygulamaları ile araştırmalar (Aksu, Çivitçi ve Duy, 2008; İlter, 2014; Kaya ve Haruroğlu, 2007; Küçükahmet, 2005) geleneksel öğretim yöntemlerini kullanmaya devam ettiklerini göstermektedir. Öğretmen ve öğretim elemanları gibi öğretmen adayları da geleneksel öğretim yöntemleri olan anlatım ve soru-cevap yöntemini uyguladıkları belirtilmektedir (Erdem ve Bayraktar, 2019; Soylu, 2009; Y1ldırım, Köklükaya ve Aydoğdu, 2016). Yapılan araştırmalar öğretmenlerin de öğretim elemanlarının da öğretmen adaylarının da öğrenen merkezli öğretim yöntem tekniklerinden çok öğretmen merkezli öğretim yöntem ve teknikleri tercih ettikleri sonucuna ulaşılmıştır. Yapılan bu araştırma hem örneklem büyüklüğü hem de değişkenler açısından şimdiye kadar yapılan birçok araştırmadan ayrılmaktadır. $\mathrm{Bu}$ araştırmada; Türkiye'de devlet ve özel eğitim kurumlarında görev yapan SBÖ'nün öğretim yöntem ve uygulamalarının incelenmesi ve değerlendirilmesi amaçlanmıştır. Bu amaçla aşağıdaki sorulara cevap aranmıştır:

1. SBÖ, hangi öğretim yöntem ve uygulamalarını kullanmaktadırlar?

2. SBÖ’nün kullandıkları öğretim yöntem ve uygulamaları cinsiyete, mezun olunan fakülteye, öğrenim durumuna, görev yapılan okul türüne, mezun olunan alana, görev yapılan bölgeye, meslekî kıdeme ve haftalık ders yüküne göre anlamlı farklılıklar göstermekte midir?

\section{Yöntem}

$\mathrm{Bu}$ bölümde araştırmanın deseni, evreni, örneklemi, veri toplama araçları ve verilerin çözümlenmesi ile ilgili bilgiler verilmiştir. Bu araştırmada, SBÖ’nün derslerinde tercih ettikleri öğretim yöntem ve uygulamalarının belirlenmesi ve değerlendirilmesi amacıyla nicel araştırma yöntemlerinden tarama (survey) yöntemi kullanılmıştır. Tarama yöntemi, sosyal bilimlerde en yaygın kullanılan veri toplama tekniğidir. Tarama yöntemi, sosyal bilimlerde en yaygın kullanılan veri toplama tekniğidir. Tarama yönteminin, telefon görüşmeleri, internet görüş anketleri ve çeşitli anket türleri vb. türleri bulunmaktadır (Neuman, 2014). Bu araştırmada bireyler anket doldurur ya da tutumları, faaliyetleri, düşünceleri ve inanışları hakkında kendileri ile görüşme yapılır (Christensen, Johnson ve Turner, 2014). Belirli bir grubun belirli özelliklerini belirlemek için verilerin toplanmasını amaçlayan çalışmalara tarama (survey) araştırması denir (Büyüköztürk, Çakmak, Akgün, Karadeniz ve Demirel, 2018; Fraenkel, Vallen ve Hyun, 2012). 


\section{Evren ve Örneklem}

Araştırmanın evrenini 2018-2019 eğitim-öğretim yılında "Türkiye Sosyal Bilgiler Zümresi” Facebook grubuna Mart 2019 itibariyle üye olan 21.892 SBÖ'dür. Araştırmada evrendeki tüm bireylerin örnekleme seçilme şansının eşit olduğu basit seçkisiz örnekleme yöntemi kullanılmıştır (Balc1, 2015; Büyüköztürk, Çakmak, Akgün, Karadeniz ve Demirel, 2018). Bu örnekleme yöntemiyle araştırmanın veri toplama aracını gönüllü olarak 631 SBÖ doldurmuştur. Evrene göre örneklem sayısının güvenirliği yüksek düzeyde olduğu söylenebilir (Cohen, Manion ve Morrison, 2007). Araştırmanın örneklemine ilişkin demografik bilgiler Tablo 1'de verilmiştir.

Tablo 1

Araştırmanın Örneklemine İlişkin Demografik Bilgiler

\begin{tabular}{|c|c|c|c|}
\hline Değişken & & $\mathrm{n}$ & $\%$ \\
\hline \multirow[t]{2}{*}{ Cinsiyet } & Kadın & 347 & 55.0 \\
\hline & Erkek & 284 & 45.0 \\
\hline \multirow[t]{2}{*}{ Mezun Olunan Fakülte } & Eğitim Fakültesi & 602 & 95.4 \\
\hline & Fen-Edebiyat Fakültesi & 29 & 4.6 \\
\hline \multirow[t]{2}{*}{ Öğrenim Durumu } & Lisans & 589 & 93.3 \\
\hline & Lisansüstü & 42 & 6.7 \\
\hline \multirow[t]{2}{*}{ Okul Türü } & Kamu & 548 & 86.8 \\
\hline & Özel & 83 & 13.2 \\
\hline \multirow{7}{*}{ Mezun Olunan Alan } & 1. Sosyal Bilgiler Öğretmenliği & 554 & 87.8 \\
\hline & 2. Tarih Öğretmenliği & 35 & 5.5 \\
\hline & 3. Coğrafya Öğretmenliği & 13 & 2.1 \\
\hline & 4. Tarih Bölümü & 15 & 2.4 \\
\hline & 5. Coğrafya Bölümü & 2 & 0.3 \\
\hline & 6. Sinıf Öğretmenliği & 7 & 1.1 \\
\hline & 7. Diğer & 5 & 0.8 \\
\hline \multirow{7}{*}{ Görev Yapılan Bölge } & 1. Marmara Bölgesi & 134 & 21.2 \\
\hline & 2. Ege Bölgesi & 89 & 14.1 \\
\hline & 3. Akdeniz Bölgesi & 80 & 12.7 \\
\hline & 4. Güneydoğu Anadolu Bölgesi & 86 & 13.6 \\
\hline & 5. Doğu Anadolu Bölgesi & 68 & 10.8 \\
\hline & 6. Karadeniz Bölgesi & 75 & 11.9 \\
\hline & 7. İç Anadolu Bölgesi & 99 & 15.7 \\
\hline \multirow{5}{*}{ Mesleki Kıdem } & 1. $1-5$ Yil & 235 & 37.2 \\
\hline & 2. $6-10 Y_{11}$ & 217 & 34.4 \\
\hline & 3. $11-15$ Y1l & 105 & 16.6 \\
\hline & 4. $16-20 Y_{11}$ & 50 & 7.9 \\
\hline & 5. 20 Üzeri Y1l & 24 & 3.8 \\
\hline \multirow{3}{*}{ Haftalık Ders Yükü } & 1. $5-15$ Saat & 69 & 10.9 \\
\hline & 2. $16-25$ Saat & 135 & 21.4 \\
\hline & 3. $26-35$ Saat & 427 & 67.7 \\
\hline Toplam & & 631 & 100 \\
\hline
\end{tabular}

Tablo 1 incelendiğinde; araştırmaya katılan SBÖ'nün 347'si kadın (\%55.0), 284'ü erkektir. Katılımcıların 602'si (\%95.4) Eğitim Fakültesi, 29'u (\%4.6) Fen-Edebiyat Fakültesi, 589'u (\%93.3) lisans, 42'si (\%6.7) lisansüstü eğitim mezunudur. Kamuya bağlı devlet okullarında 548 (\%86.8), özel okullarda 83 (\%13.2) SBÖ görev yapmaktadır. SBÖ olarak görev yapanların 554'ü (\%87.8) Sosyal Bilgiler Öğretmenliği 35 'i (5.5) Tarih Öğretmenliği, 13’ü (\%2.1) Coğrafya Öğretmenliğii, 15'i (\%2.4) Tarih Bölümü, 2'si (\%0.3) Coğrafya Bölümü, 7'si (1.1) Sınıf Öğretmenliği, 5’i (\%0.8) diğer alanlardan mezun olmuşlardır. Araştırmaya katılan SBÖ’nün 134'ü (\%21.2) Marmara Bölgesi'nde, 89’u (\%14.1) Ege Bölgesi’nde, 80’i (\%12.7) Akdeniz Bölgesi'nde, 86’sı (\%13.6) Güneydoğu Anadolu Bölgesi'nde, 68'i (\%10.8) Doğu Anadolu Bölgesi’nde, 75’i (\%11.9) Karadeniz Bölgesi’nde, 99'u (\%15.7) İç Anadolu Bölgesi’nde görev yapmaktadır. Diğer yandan bu öğretmenlerin 235'i (\%37.2) "1 - 5 y1l”, 217'si (\%34.3) “6 - 10” y1l, 105’i (\%16.6) “11 - 15 y1l”, 50’si (\%7.9) "16 - 20 y1l” ve 24’ü 
(\%3.8) "20 y1ldan fazla" meslekî kıdeme sahip olup; 69'u (\%10.9) haftada 5 - 15, 135'i (\%21.4) haftada 16 - 24, 427'si (\%67.7) haftada 26 - 35 saat derse girmektedirler. Araştırmaya katılan SBÖ’nün yarıdan fazlası kadın, çoğunluğu eğitim fakültesi ve lisans mezunudur. Büyük oranda SBÖ lisans mezunu olup 1 - 10 yıl meslekî kıdeme sahip, haftada 25 saatten fazla derse giren ve ağırlıklı olarak Marmara Bölgesi’nde görev yapan bir örneklem grubu olduğu söylenebilir.

\section{Veri Toplama Araçları ve Uygulama}

Araştırmanın veri toplama araçları, SBÖ’nün bilgilerini öğrenmek amacıyla "Kişisel Bilgi Formu” ve İlter'in (2018) geliştirdiği 30 maddelik Likert tipi “Sosyal Bilgiler Öğretim Yöntem ve Uygulamalarl" ölçeğidir. Bu ölçeği geliştiren araştırmacıdan izin alınarak "Türkiye Sosyal Bilgiler Zümresi” Facebook grubuna üye olan SBÖ’ler tarafından çevrimiçi olarak toplanmıştır. Ölçek "Türkiye Sosyal Bilgiler Zümresi" Facebook grubunda bir hafta süreyle doldurulmaya açık bırakılmıştır. Ölçeğin doldurulmasına "Türkiye Sosyal Bilgiler Zümresi” Facebook grubu yöneticisi de yardımcı olmuştur. Ölçek vasıtasıyla toplanan verileri çözümlemek için ölçekteki cevaplara belirli puanlar verilmiştir. SBÖ’nün Sosyal Bilgiler konularının öğretiminde uyguladığı öğretim yöntem ve uygulamaların yanında bu yöntem ve uygulamaları kullanma sıklığının belirtilmesini gerektiren maddeler "1- Derste hiçbir zaman, 2-Nadiren, 3-Ara sıra, 4-Çoğu zaman, 5-Derste her zaman" şeklinde değerlendirilmiştir. Bu çalışmada ise ölçeğin Cronbach Alpha değeri, 0.92. yapı geçerlilik değeri olan KMO değeri ise 0.941 olarak bulunmuştur.

\section{Verilerin Çözümlenmesi}

Araştırma bağımlı değişkenlerin normal dağılım gösterip göstermediğini tespit için tek örneklemli Kolmogorov Smirnov testi yapılmıştır. Elde edilen sonuçlara göre bağımlı değişkenlerin normal dağılım gösterdiği belirlenmiştir [ "Sosyal Bilgiler Öğretim Yöntem ve Uygulamaları" ölçeği $\mathrm{K}-\mathrm{S}(\mathrm{z})=3.698 ; \mathrm{p}$ : 0.05]. Aynı zamanda verilerin normal dağılım gösterip göstermediğini tespit için kurtosis ve skewness değerlerine de bakılmıştır. Yapılan analizde verilerin normal dağılım gösterdiği belirlenmiştir (Skewness: -.196; Kurtosis: 0.397). Verilerin çözümlemesinde betimleyici istatistikler (örn., frekans, yüzde, ortalama), güvenilirlik analizi, t-testi, tek yönlü varyans (ANOVA) ve LSD testi kullanılmıştır. Elde edilen değerlerin etki büyüklükleri hesaplanırken bağımsız gruplar t-testi için Cohen $d$ formülü; tek yönlü varyans analizi için Cohen $f$ formülü kullanılmıştır. Cohen $d$ değeri için .20 ve altı küçük-düşük; .20-.80 arası orta; .80 ve üstü için geniş-büyük düzey; Cohen $f$ değeri için .10 küçük; .30 orta; .50 geniş düzey etki büyüklüğü değerleri temele alınmıştır. Bahsedilen analizlerin yapılması için Jamovi 1.0.6. ve SPSS 25.00 istatistik programı kullanılmıştır.

\section{Bulgular}

Araştırmadan elde edilen bulgular araştırma soruları bağlamında sırasıyla tablolar halinde verilmiştir. SBÖ'nün tercih ettikleri öğretim yöntem ve uygulamalarına ilişkin aritmetik ortalama ve standart sapma değerleri Tablo 2'de verilmiştir.

Tablo 2

SBÖ’nün Öğretim Yöntem ve Uygulamaları Ölçeği Puanlarına İlişkin Aritmetik Ortalama ve Standart Sapma Değerleri

\begin{tabular}{lccc}
\hline Faktörler & $\mathrm{n}$ & $\overline{\mathrm{x}}$ & $\mathrm{Ss}$ \\
\hline Pasif Öğrenme Yöntemleri & 631 & 4.05 & .529 \\
Öğrenen Merkezli Uygulamalar & 631 & 3.53 & .615 \\
Bilişsel Strateji Öğretimi & 631 & 3.58 & .740 \\
\hline
\end{tabular}

Tablo 2'de ölçeğin faktörlerine ilişkin elde edilen verilere göre; "Pasif öğrenme yöntemleri" $(\overline{\mathrm{x}}=4.05 ; \mathrm{Ss}=.529)$ faktöründe en yüksek ortalama belirlenirken, "Bilişsel strateji ögretimi" $(\overline{\mathrm{x}}=3.53$, $\mathrm{Ss}=.615)$ faktöründe en düşük ortalama belirlenmiştir. "Öğrenen merkezli uygulamalar" adlı faktörün ortalamas1 ise $\overline{\mathrm{x}}=3.58 \mathrm{Ss}=.740$ olarak bulunmuştur. $\mathrm{Bu}$ sonuçlara göre araştırmaya katılan öğretmenlerin çoğunluğunun derslerinde öğreneni merkeze alan öğrenme uygulamalarından çok 
öğretmeni merkeze alan öğretme uygulamalarını kullandıkları söylenebilir. SBÖ’nün öğretim yöntem ve uygulamaları ölçeği puanlarının cinsiyet değişkenine göre t testi sonuçları Tablo 3'te verilmiştir.

Tablo 3

SBÖ’nün Öğretim Yöntem ve Uygulamaları Ölçeği Puanlarının Cinsiyet Değişkenine Göre t Testi Sonuçlart

\begin{tabular}{llcccccc}
\hline Faktörler & Cinsiyet & $\mathrm{n}$ & $\overline{\mathrm{x}}$ & $\mathrm{S}$ & $\mathrm{t}$ & $\mathrm{p}$ & Cohen $d$ \\
\hline Pasif Öğrenme Yöntemleri & Kadın & 347 & 4.12 & .51 & 3.818 & $.00^{*}$ & .30 \\
& Erkek & 284 & 3.96 & .53 & & & \\
Öğgrenen Merkezli Uygulamalar & Kadın & 347 & 3.59 & .60 & 2.426 & $.01 *$ & .20 \\
& Erkek & 284 & 3.47 & .61 & & & \\
\multirow{2}{*}{ Bilişssel Strateji Ö Ŏretimi } & Kadın & 347 & 3.65 & .74 & 2.465 & $.01 *$ & .19 \\
& Erkek & 284 & 3.50 & .73 & & & \\
\hline \multicolumn{1}{c}{ p $<05$} & & & & & & &
\end{tabular}

Tablo 3 incelendiğinde; SBÖ’nün cinsiyet değişkenine göre öğretim yöntem ve uygulamaları arasında anlamlı bir farklılaşma olduğu görülmektedir. Buna göre; kadın SBÖ'nün erkeklere nazaran derslerinde pasif öğrenme yöntemlerine, öğrenen merkezli uygulamalara ve bilişsel strateji öğretim uygulamalarına daha fazla yer verildiği görülmektedir. Diğer yandan anlamlı farklılıkların etki büyüklüğ̈̈ değerleri (Cohen $d$ ) incelendiğinde, SBÖ'nün "Pasif ögrenme yöntemleri” faktöründe orta düzeyde, "Öğrenen merkezli uygulamalar" faktöründe orta düzeyde ve "Bilişsel strateji ögrretimi" faktöründe düşük düzeyde olduğu görülmektedir. SBÖ’nün öğretim yöntem ve uygulamaları ölçeği puanlarının fakülte değişkenine göre $t$ testi sonuçları Tablo 4'te verilmiştir.

Tablo 4

SBÖ’nün Öğretim Yöntem ve Uygulamaları Ölçeği Puanlarının Mezun Olunan Fakülte Değişkenine Göre t Testi Sonuçlart

\begin{tabular}{llcccccc}
\hline Faktörler & Fakülte & $\mathrm{n}$ & $\overline{\mathrm{x}}$ & $\mathrm{S}$ & $\mathrm{t}$ & $\mathrm{p}$ & Cohen $d$ \\
\hline Pasif Öğrenme & Eğitim Fakültesi & 602 & 4.05 & .52 & -1.026 & .30 & - \\
Yöntemleri & Fen-Edebiyat Fakültesi & 29 & 4.15 & .57 & & & \\
Öğrenen Merkezli & Eğitim Fakültesi & 602 & 3.52 & .61 & -2.775 & $.00 *$ & .51 \\
Uygulamalar & Fen-Edebiyat Fakültesi & 29 & 3.84 & .62 & & & \\
Bilişsel Strateji & Eğitim Fakültesi & 602 & 3.57 & .73 & -2.322 & $.02 *$ & .44 \\
Öğretimi & Fen-Edebiyat Fakültesi & 29 & 3.89 & .83 & & & \\
\hline
\end{tabular}

Tablo 4'te araştırmaya katılan SBÖ’nün mezun oldukları fakülteye göre derslerindeki yöntem ve uygulamaları incelenmiştir. Buna göre eğitim fakültesi ve fen-edebiyat fakültesinden mezun olan SBÖ daha çok pasif öğrenme yöntemlerini uygulamaktadırlar. Mezun olunan fakülteler arasında anlamlı farkl11ı bulunmaktadır. Bu farkl11ıkların "Öğrenen merkezli uygulamalar" ve "Bilişsel strateji ögretimi” faktörlerinde olduğu görülmektedir. Anlamlı farklılıkların etki büyüklüğü değerleri (Cohen $d$ ) incelendiğinde, SBÖ'nün "Öğrenen merkezli uygulamalar" faktöründe ve "Bilişsel strateji ögretimi" faktöründe orta düzeyde olduğu görülmektedir. Fen-edebiyat fakültesi mezunu SBÖ eğitim fakültesi mezunlarına göre derslerinde öğrenen merkezli ve bilişsel strateji gelişimine yönelik uygulamalarına daha çok yer verdikleri, eğitim fakültesi mezunları SBÖ’nün de daha çok pasif öğrenme yöntemlerini tercih ettikleri görülmektedir. SBÖ'nün öğretim yöntem ve uygulamaları ölçeği puanlarının ögrrenim durumu değişkenine göre t testi sonuçları Tablo 5'te verilmiş̧tir.

Tablo 5

SBÖ’nün Öğretim Yöntem ve Uygulamaları Ölçeği Puanlarının Öğrenim Durumu Değişkenine Göre t Testi Sonuçlart

\begin{tabular}{llccccc}
\hline Faktörler & Öğrenim Durumu & $\mathrm{N}$ & $\overline{\mathrm{x}}$ & $\mathrm{S}$ & $\mathrm{t}$ & $\mathrm{p}$ \\
\hline Pasif Öğrenme Yöntemleri & Lisans & 589 & 4.05 & .52 & -.479 & .63 \\
& Lisansüstü & 42 & 4.09 & .56 & & \\
Öğrenen Merkezli Uygulamalar & Lisans & 589 & 3.53 & .61 & -1.109 & .26 \\
\hline
\end{tabular}




\begin{tabular}{llccccc}
\hline \multirow{3}{*}{ Bilişsel Strateji Öğretimi } & Lisansüstü & 42 & 3.64 & .67 & & \\
& Lisans & 589 & 3.58 & .73 & -.516 & .60 \\
& Lisansüstü & 42 & 3.64 & .80 & & \\
\hline
\end{tabular}

Tablo 5'te; SBÖ’nün öğretim yöntem ve uygulamaları öğrenim durumu değişkenine göre incelenmiştir. Lisans ve lisansüstü eğitim mezunu olan SBÖ arasında öğretim yöntem ve uygulamalarına yönelik bir anlamlı farklılık olmadığı bulgusuna ulaşılmıştır. Bu durumda; öğrenim durumunun SBÖ'nün derslerinde kullandıkları öğretim yöntem ve uygulamalarına etkisi olmadığı söylenebilir. Alanında lisansüstü eğitim yapan bir bireyin daha yapmayanlara göre mesleğinde daha etkili olması beklenir. Ancak bunun yapılan bu araştırma sonuçlarına ile benzerlik göstermediği ifade edilebilir. SBÖ'nün öğretim yöntem ve uygulamaları ölçeği puanlarının görev yapılan okul türü değişkenine göre t testi sonuçları Tablo 6'da verilmiştir.

Tablo 6

SBÖ’nün Öğretim Yöntem ve Uygulamaları Ölçeği Puanlarının Görev Yapılan Okul Türü Değişkenine Göre t Testi Sonuçları

\begin{tabular}{lccccccc}
\hline Faktörler & Okul Türü & $\mathrm{N}$ & $\overline{\mathrm{x}}$ & $\mathrm{S}$ & $\mathrm{t}$ & $\mathrm{p}$ & Cohen $d$ \\
\hline Pasif Öğrenme Yöntemleri & Kamu & 548 & 4.04 & .52 & -1.016 & .31 & - \\
& Özel & 83 & 4.10 & .58 & & & \\
Öğrenen Merkezli Uygulamalar & Kamu & 548 & 3.49 & .60 & -4.863 & $.00 *$ & .55 \\
& Özel & 83 & 3.83 & .63 & & & \\
Bilişsel Strateji Öğretimi & Kamu & 548 & 3.54 & .73 & -3.922 & $.00 *$ & .46 \\
& Özel & 83 & 3.87 & .70 & & & \\
\hline
\end{tabular}

Tablo 6 incelendiğinde; araştırmaya katılan SBÖ’nün derslerinde kullandıkları öğretim yöntem ve uygulamalarının çalıştıkları okul türüne göre anlamlı farklılıklar olduğu görülmektedir. Buna göre; "Pasif ögrrenme yöntemleri" faktöründe kamu ve özel okulda görev yapan SBÖ’nün ortalama puanları arasında anlamlı bir farklılı̆̆ın olmadığı bulgusuna ulaşılmıştır. Ancak "Öğrenen merkezli uygulamalar" ve "Bilişsel strateji öğretimi" faktörlerinde kamu ve özel okulda görev yapan SBÖ’nün ortalama puanları arasında özel okulda görev yapan SBÖ lehine anlamlı bir farkl1lık olduğu görülmektedir. Anlamlı farklılıkların etki büyüklüğü değerleri (Cohen d) incelendiğinde, SBÖ’nün "Öğrenen merkezli uygulamalar" faktöründe ve "Bilişsel strateji ögretimi” faktöründe orta düzeyde olduğu görülmektedir. Bu durumda özel okulda çalışan SBÖ çeşitli nedenlerden öğreneni öğretim süreçlerinin merkezine daha çok yerleştirmektedirler. Bu durumun en önemli nedenlerinden birisinin mesleğini kaybetme korkusu olduğu söylenebilir. SBÖ’nün öğretim yöntem ve uygulamaları ölçeği puanlarının mezun olunan alan değişkenine göre tek yönlü varyans analizi (One-Way Anova) sonuçları Tablo 7'de verilmiştir.

Tablo 7

SBÖ’nün Öğretim Yöntem ve Uygulamaları Ölçeği Puanlarının Mezun Olunan Alan Değişkenine Göre Tek Yönlü Varyans Analizi Sonuçları

\begin{tabular}{|c|c|c|c|c|c|c|c|c|}
\hline Faktörler & Mezun Olunan Alan & $\mathrm{N}$ & $\overline{\mathrm{x}}$ & $\mathrm{Sd}$ & $\mathrm{F}$ & $\mathrm{p}$ & Fark (LSD) & Cohen $f$ \\
\hline \multirow{7}{*}{ 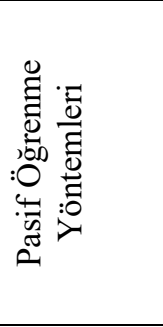 } & Sosyal Bilgiler Öğretmenliği & 554 & 4.06 & 0.517 & \multirow{7}{*}{5.07} & \multirow{7}{*}{$.01 *$} & \multirow{7}{*}{$\begin{array}{l}5 *_{-} 6,6-7 * \\
1 *_{-} 6,3 *_{-}-5 \\
2 *_{-} 6,3 *_{-} 6 \\
4 *_{-} 6,2 *_{-}-5\end{array}$} & \multirow{7}{*}{.28} \\
\hline & Tarih Öğretmenliği & 35 & 3.94 & 0.568 & & & & \\
\hline & Coğrafya Öğretmenliği & 13 & 4.21 & 0.481 & & & & \\
\hline & Sınıf Öğretmenliği & 7 & 3.25 & 0.470 & & & & \\
\hline & Tarih & 15 & 4.02 & 0.588 & & & & \\
\hline & Coğrafya & 2 & 4.72 & 0.236 & & & & \\
\hline & Diğer & 5 & 4.36 & 0.709 & & & & \\
\hline \multirow{4}{*}{ 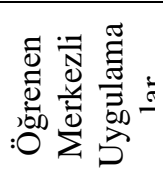 } & Sosyal Bilgiler Öğretmenliği & 554 & 3,53 & 0.609 & & & & \\
\hline & Tarih Öğretmenliği & 35 & 3,56 & 0.603 & & & \multirow{3}{*}{$\begin{array}{l}1-5^{*}, 1-7^{*} \\
2-5^{*}, 3-5^{*}\end{array}$} & \multirow[b]{3}{*}{.40} \\
\hline & Coğrafya Öğretmenliği & 13 & 3,39 & 0.666 & & & & \\
\hline & Sinıf Öğretmenliği & 7 & 3,75 & 0.564 & & & & \\
\hline
\end{tabular}




\begin{tabular}{|c|c|c|c|c|c|c|c|c|}
\hline & Tarih & 15 & 4,52 & 0.432 & & & \multirow{3}{*}{$\begin{array}{l}3-7 *, 4^{*}-6 \\
5^{*}-6,6-7^{*}\end{array}$} & \\
\hline & Coğrafya & 2 & 3,11 & 0.591 & 2.65 & $.01 *$ & & \\
\hline & Diğer & 5 & 4,11 & 0.819 & & & & \\
\hline \multirow{7}{*}{ 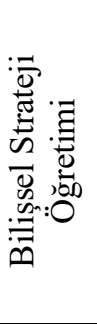 } & Sosyal Bilgiler Öğretmenliği & 554 & 3.58 & 0.736 & \multirow{7}{*}{8.82} & \multirow{7}{*}{$.00 *$} & \multirow{7}{*}{$\begin{array}{l}1-5^{*}, 1^{*}-6, \\
1-7^{*}, 2-5^{*}, \\
2^{*}-6,3-5^{*}, \\
3^{*}-6,4^{*}-6, \\
5^{*}-6,6-7 *\end{array}$} & \multirow{7}{*}{.34} \\
\hline & Tarih Öğretmenliği & 35 & 3.64 & 0.711 & & & & \\
\hline & Coğrafya Öğretmenliği & 13 & 3.54 & 0.660 & & & & \\
\hline & Sınıf Öğretmenliği & 7 & 2.86 & 0.634 & & & & \\
\hline & Tarih & 15 & 3.80 & 0.764 & & & & \\
\hline & Coğrafya & 2 & 4.83 & 0.236 & & & & \\
\hline & Diğer & 5 & 4.27 & 0.760 & & & & \\
\hline
\end{tabular}
Bölümü, 6. Sınıf Öğretmenliği, 7. Diğer.

Tablo 7 incelendiğinde; katılımcı SBÖ’nün derslerinde kullandıkları öğretim yöntem ve uygulamalarının mezun oldukları alana göre değerlendirilmiştir. Buna göre; bütün faktörlerde anlamlı farklılıkların oluştuğu görülmektedir. "Pasif öğrenme yöntemleri" faktöründe bu anlamlı farkl1lıklar; coğrafya bölümü ve sınıf öğretmenliği, diğer ve sınıf öğretmenliği, Sosyal Bilgiler öğretmenliği ve sınıf öğretmenliği, coğrafya öğretmenliği ve coğrafya bölümü, tarih öğretmenliği ve sınıf öğretmenliği, coğrafya öğretmenliği ve sinıf öğretmenliği, tarih bölümü ve sinıf öğretmenliği, tarih öğretmenliği ve coğrafya bölümleri arasında ilk sırada yazılanların lehinedir. "Öğrenen merkezli uygulamalar" faktöründe anlamlı farklılıklar; coğrafya bölümü ve sosyal bilgiler öğretmenliği, diğer ve sosyal bilgiler öğretmenliği, coğrafya bölümü ve tarih öğretmenliği, coğrafya bölümü ve coğrafya öğretmenliği, diğer ve coğrafya öğretmenliği, tarih bölümü ve coğrafya bölümü, coğrafya bölümü ve sınıf öğretmenliği, diğer ve sınıf öğretmenliği arasında ilk sırada belirtilen alandan mezun olan öğretmenlerin lehinedir. "Bilişsel strateji ögretimi” faktöründe anlamlı farkl1lıklar; coğrafya bölümü ve sosyal bilgiler öğretmenliği, sosyal bilgiler öğretmenliği ve sınıf öğretmenliği, diğer ve sosyal bilgiler öğretmenliği, coğrafya bölümü ve taeih öğretmenliğii, tarih öğretmenliği ve sınıf öğretmenliği, coğrafya bölümü ve coğrafya öğretmenliği, coğrafya öğretmenliği ve sınıf öğretmenliği, tarih bölümü ve sınıf öğretmenliği, coğrafya bölümü ve sınıf öğretmenliği, diğer ve sınıf öğretmenliği arasında ilk sırada belirtilen alandan mezun olan öğretmenlerin lehinedir. Anlamlı farklılıkların etki büyüklüğü değerleri (Cohen $f$ ) incelendiğinde, SBÖ'nün "pasif ögrenme yöntemleri", "öğrenen merkezli uygulamalar" ve "bilişsel strateji ögretimi” faktöründe orta düzeyde olduğu görülmektedir. SBÖ’nün öğretim yöntem ve uygulamaları ölçeği puanlarının görev yapılan bölge değişkenine göre tek yönlü varyans analizi sonuçları Tablo 8'de verilmiştir.

Tablo 8

SBÖ’nün Öğretim Yöntem ve Uygulamaları Ölçeği Puanlarının Görev Yapılan Bölge Değişkenine Göre Tek Yönlü Varyans Analizi Sonuçları

\begin{tabular}{|c|c|c|c|c|c|c|}
\hline Faktörler & Bölge & $\mathrm{N}$ & $\overline{\mathrm{x}}$ & $\mathrm{Sd}$ & $\mathrm{F}$ & $\mathrm{p}$ \\
\hline \multirow{7}{*}{ 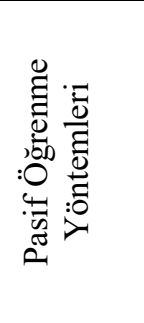 } & Doğu Anadolu Bölgesi & 68 & 4.11 & 0.502 & \multirow{7}{*}{0.723} & \multirow{7}{*}{.63} \\
\hline & Akdeniz Bölgesi & 80 & 4.02 & 0.532 & & \\
\hline & Ege Bölgesi & 89 & 4.08 & 0.477 & & \\
\hline & Karadeniz Bölgesi & 75 & 4.04 & 0.625 & & \\
\hline & Güneydoğu Anadolu Bölgesi & 86 & 4.01 & 0.534 & & \\
\hline & İç Anadolu Bölgesi & 99 & 4.00 & 0.562 & & \\
\hline & Marmara Bölgesi & 134 & 4.11 & 0.491 & & \\
\hline \multirow{7}{*}{ 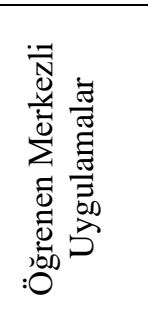 } & Doğu Anadolu Bölgesi & 68 & 3.52 & 0.570 & \multirow{7}{*}{1.19} & \multirow{7}{*}{.30} \\
\hline & Akdeniz Bölgesi & 80 & 3.62 & 0.614 & & \\
\hline & Ege Bölgesi & 89 & 3.52 & 0.613 & & \\
\hline & Karadeniz Bölgesi & 75 & 3.62 & 0.623 & & \\
\hline & Güneydoğu Anadolu Bölgesi & 86 & 3.43 & 0.621 & & \\
\hline & İç Anadolu Bölgesi & 99 & 3.58 & 0.539 & & \\
\hline & Marmara Bölgesi & 134 & 3.61 & 0.592 & & \\
\hline
\end{tabular}




\begin{tabular}{|c|c|c|c|c|c|c|}
\hline \multirow{7}{*}{ 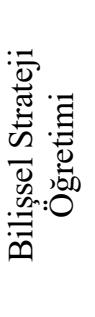 } & Doğu Anadolu Bölgesi & 68 & 3.63 & 0.682 & \multirow{7}{*}{0.858} & \multirow{7}{*}{.52} \\
\hline & Akdeniz Bölgesi & 80 & 3.70 & 0.702 & & \\
\hline & Ege Bölgesi & 89 & 3.46 & 0.780 & & \\
\hline & Karadeniz Bölgesi & 75 & 3.55 & 0.801 & & \\
\hline & Güneydoğu Anadolu Bölgesi & 86 & 3.60 & 0.723 & & \\
\hline & İç Anadolu Bölgesi & 99 & 3.54 & 0.734 & & \\
\hline & Marmara Bölgesi & 134 & 3.62 & 0.747 & & \\
\hline
\end{tabular}

Tablo 8 incelendiğinde; SBÖ’nün öğretim yöntem ve uygulamaları görev yapılan bölge değişkenine göre incelenmiş ve anlamlı farkl1lıklar göstermemiştir. Buna göre SBÖ’nün derslerinde tercih ettikleri yöntem ve uygulamalar görev yapılan bölgeye göre değişmemektedir. Ancak SBÖ’den elde edilen ölçek toplam puanlarına göre "Pasif ögrenme yöntemleri" faktör toplam puanları "Öğrenen merkezli uygulamalar" ve "Bilişsel strateji öğretimi" faktör toplam puanlarına nazaran daha fazla olduğu sonucuna ulaşılmıştır. Bu durumda SBÖ’nün görev yapılan bölge değişkeni dikkate alınmaksızın derslerinde pasif öğrenme yöntemlerini daha fazla tercih ettikleri sonucunu ortaya çıkarmaktadır. SBÖ’nün öğretim yöntem ve uygulamaları ölçeği puanlarının meslekî kıdem değişkenine göre tek yönlü varyans analizi sonuçları Tablo 9'da verilmiştir.

Tablo 9

SBÖ’nün Öğretim Yöntem ve Uygulamaları Ölçeği Puanlarının Meslekî Kıdem Değisşkenine Göre Tek Yönlü Varyans Analizi Sonuçları

\begin{tabular}{|c|c|c|c|c|c|c|c|c|}
\hline Faktörler & Meslekî Kıdem & $\mathrm{N}$ & $\overline{\mathrm{x}}$ & $\mathrm{Sd}$ & $\mathrm{F}$ & $\mathrm{p}$ & Fark (LSD) & Cohen $f$ \\
\hline \multirow{5}{*}{ 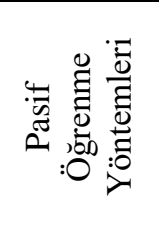 } & $1-5 Y_{11}$ & 235 & 4.04 & 0.563 & \multirow{5}{*}{2.82} & \multirow{5}{*}{$.02 *$} & \multirow{5}{*}{$\begin{array}{l}1^{*}-5 \\
2^{*-5} \\
3 *-4, \\
3^{*}-5\end{array}$} & \multirow{5}{*}{.49} \\
\hline & $6-10 Y_{11}$ & 217 & 4.08 & 0.493 & & & & \\
\hline & $11-15 Y_{11}$ & 105 & 4.15 & 0.468 & & & & \\
\hline & $16-20 Y_{11}$ & 50 & 3.94 & 0.528 & & & & \\
\hline & 20 ve üzeri & 24 & 3.79 & 0.653 & & & & \\
\hline \multirow{5}{*}{ 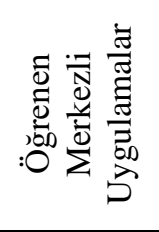 } & $1-5 Y_{11}$ & 235 & 3.53 & 0.647 & \multirow{5}{*}{0.895} & \multirow{5}{*}{.47} & & \\
\hline & $6-10 Y_{11}$ & 217 & 3.61 & 0.545 & & & & \\
\hline & $11-15$ Y 11 & 105 & 3.57 & 0.588 & & & & \\
\hline & $16-20 Y_{11}$ & 50 & 3.53 & 0.536 & & & & \\
\hline & 20 ve üzeri & 24 & 3.43 & 0.676 & & & & \\
\hline \multirow{5}{*}{ 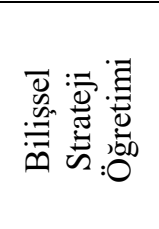 } & $1-5$ Yil & 235 & 3.61 & 0.740 & \multirow{5}{*}{1.24} & \multirow{5}{*}{.29} & & \\
\hline & $6-10$ Y1l & 217 & 3.64 & 0.730 & & & & \\
\hline & $11-15$ Y11 & 105 & 3.52 & 0.747 & & & & \\
\hline & $16-20 Y_{11}$ & 50 & 3.51 & 0.657 & & & & \\
\hline & 20 ve üzeri & 24 & 3.31 & 0.922 & & & & \\
\hline
\end{tabular}

Tablo 9 incelendiğinde; SBÖ’nün tercih ettiği öğretim yöntem ve uygulamaları meslekî kıdem değişkenine göre incelendiği görülmektedir. SBÖ’nün meslekî kıdem değişkenine göre sadece "pasif ögrenme yöntemleri" faktöründe anlamlı bir farklılaşma olduğu görülmüştür. Bu anlamlı farklılaşma;

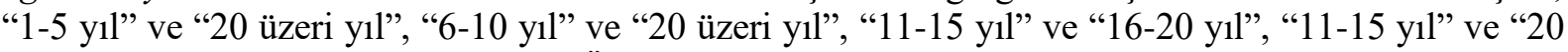
üzeri yıl" meslekî kıdeme sahip SBÖ arasından olduğu görülmektedir. Bu durum da araştırmaya katılan SBÖ’nün meslekî kıdemleri arttıkça pasif öğrenme yöntemlerinin yani öğretmen merkezli öğrenme yöntemlerini daha fazla kullandıkları, meslekî kıdemleri azaldıkça öğrenen merkezli yöntem ve uygulamaları daha fazla kullandıkları sonucunu ortaya çıkarmıştır. Anlamlı farklılıkların etki büyüklüğü değerleri (Cohen $f$ ) incelendiğinde, SBÖ’nün "Pasif öğrenme yöntemleri” faktöründe orta düzeyde olduğu görülmektedir. SBÖ’nün öğretim yöntem ve uygulamaları ölçeği puanlarının haftalık ders yükü değişkenine göre tek yönlü varyans analizi sonuçları Tablo 10'da verilmiştir. 
Tablo 10

SBÖ'nün Öğretim Yöntem ve Uygulamaları Ölçeği Puanlarının Haftalık Ders Yükü Değişkenine Göre Tek Yönlü Varyans Analizi Sonuçları

\begin{tabular}{|c|c|c|c|c|c|c|}
\hline Faktörler & Bölge & $\mathrm{N}$ & $\overline{\mathrm{X}}$ & $\mathrm{Sd}$ & $\mathrm{F}$ & $\mathrm{p}$ \\
\hline \multirow{3}{*}{ Pasif Öğrenme Yöntemleri } & $26-35$ Saat & 427 & 4.05 & 0.525 & \multirow{3}{*}{0.084} & \multirow{3}{*}{.91} \\
\hline & 16 - 25 Saat & 135 & 4.07 & 0.508 & & \\
\hline & $5-15$ Saat & 69 & 4.05 & 0.602 & & \\
\hline \multirow{3}{*}{ Öğrenen Merkezli Uygulamalar } & $26-35$ Saat & 427 & 3.55 & 0.603 & \multirow{3}{*}{1.65} & \multirow{3}{*}{.19} \\
\hline & 16 - 25 Saat & 135 & 3.53 & 0.578 & & \\
\hline & 5 - 15 Saat & 69 & 3.68 & 0.585 & & \\
\hline \multirow{3}{*}{ Bilişsel Strateji Öğretimi } & 26-35 Saat & 427 & 3.59 & 0.726 & \multirow{3}{*}{0.030} & \multirow{3}{*}{.97} \\
\hline & 16 - 25 Saat & 135 & 3.57 & 0.780 & & \\
\hline & 5 - 15 Saat & 69 & 3.60 & 0.757 & & \\
\hline
\end{tabular}

Tablo 10'da SBÖ'nün tercih ettiği öğretim yöntem ve uygulamaları meslekî kıdem değişkenine göre incelenmiştir. Araştırmaya katılan SBÖ'nün tercih ettikleri öğretim yöntem ve uygulamaları öğretmenlerin haftalık ders yükü değişkenine göre ölçeğin "Pasif ögrenme yöntemleri", "Öğrenen merkezli uygulamalar" ve "Bilişsel Strateji Öğretimi" faktörlerinde anlamlı farkl1lıklara rastlanılmamıştır. Bu durumda haftada daha az derse giren ve daha çok derse giren SBÖ'nün tercih ettikleri öğretim yöntem ve uygulamaları değişmemektedir. Daha az derse giren SBÖ'nün kullanacakları öğretim yöntem ve uygulamalar ile ilgili hazırlık yapma vakti olmasına rağmen daha çok derse giren öğretmenden farklı olarak öğrenen merkezli öğretim yöntem ve uygulamalar kullanılmıyor ise bu konuda yetersiz oldukları söylenebilir.

\section{Sonuç, Tartışma ve Öneriler}

Araştırmanın bulgularına göre; SBÖ'nün tercih ettiği öğretim yöntem ve uygulamaları öğrenim durumu, görev yapılan bölge, haftalık ders yükü ve mesleki kıdem değişkenlerine göre anlamlı farklılıklar göstermemekle birlikte; cinsiyet, mezun olunan fakülte, mezun olunan branş, görev yapılan okul türü değişkenlerine göre anlamlı farklılıklar göstermiştir. Araştırmadan elde edilen anlamlı farklılıklar şöyledir; SBÖ’ler, öğretim yöntem ve uygulamalarında en çok "Pasif ögrrenme yöntemleri” "ni kullanmaktadırlar. Öğretmenler kendilerinin merkezde olduğu öğretim yöntem, teknik, stratejilere öncelikle ağırlık vermekte ve özellikle öğrenen merkezli yöntem, teknik ve stratejilerden uzak durma eğilimindedirler (Covill, 2011; Faruji, 2012; Grasha, 1994; Junst, Licklider ve Wiersema, 2003; Martinez, 2003; Marbach, Seal ve Sokolove 2001; Mendoza, 2004; Oh ve Kim, 2013). Bu durum da öğretmenlerin çağdaş öğretim yöntem, teknik ve stratejilerini kullanmaları konusundaki yetersizliklerinden kaynaklanmaktadır (Kayabaşı, 2012). Yapılan araştırmalara göre (Önen, Saka, Erdem, Uzal ve Gürdal, 2008) farklı branşlardaki öğretmenlerin derslerinde öğretim yöntem-teknik ve stratejilere ilişkin yeterli bilgi ve beceriye sahip olmadıklarından, genellikle öğretmeni merkeze alan yöntem-teknik ve stratejileri tercih ettikleri gözlenmiştir. Öğretmenler arasında en yaygın olarak kullanılan öğretim yöntemleri arasında, sıkıcı ve etkisiz yöntem olarak nitelendirilen düz anlatım ve soru-cevap yöntemleri gelmektedir (Klein, Matkins ve Weaver, 1999). Çelikkaya ve Kuş'un (2009) araştırma sonucuna göre; sınıf içerisinde öğretmenler en çok, soru-cevap, düz anlatım, yazdırma yöntemi ve beyin firtınası yöntemini kullanmaktadır. Araştırmaya katılan SBÖ'nün daha çok öğretmen merkezli pasif öğrenme yöntemleri kullanıldığı görülmektedir. Bu duruma sebep olarak; öğretmenlerin üniversitede öğrenim görürken öğrendikleri bilgileri sınıf ortamında uygulayamadıkları (Sutton, 2003), sınıf mevcutlarının fazla olması (Doğru ve Aydoğdu, 2003), Türkiye'deki okulların fiziki yapılarının öğretmenlerin rahat hareket edebilecek çeşitli öğretim yöntem ve teknikleri uygulayabilecek esnek yapıya sahip olmadıkları, öğretmenlerin çeşitli öğretim yöntem ve teknik bilmelerine rağmen sınıf ortamına bu bilgilerini yansıtamadıkları (Çelikkaya ve Kuş, 2009; Demir ve Özden, 2013; Demircioğlu, Genç ve Demircioğlu, 2015) söylenebilir.

Araştırmaya katılan kadın SBÖ’ler, “Öğrenen merkezli uygulamalar" ve "Bilişsel strateji ögretimi” gibi aktif öğrenme yöntemlerini erkek SBÖ’ye nazaran daha çok kullanmaktadırlar. 
Aydemir (2012) yaptığı araştırmasında; resmi ve özel okullarda görev yapan kadın SBÖ’nün erkek SBÖ'ye göre örnek olay ve rol oynama/drama yöntemini daha çok kullandığını ifade etmiştir. Diğer yandan Ocak vd. (2012) araştırmalarında; kadın ve erkek öğretmenlerin öğretim yöntem ve tekniklerine yönelik tutumlarının birbirlerine benzer olduğunu ifade etmişlerdir. Eskici ve Çetinkaya da (2019) yaptığ 1 araştırmada öğretmenlerin cinsiyetleri ile öğretim yöntem ve teknikleri arasında anlamlı bir farklılığa rastlamamıştır. Yapılan araştırmaların genelinde kadın öğretmenlerin öğretim yöntem ve teknik kullanımında erkek öğretmenlere göre etkin olduğunu ifade etmektedir (Babadoğan, 1996; Eroğlu 2007). Bu durumun sebebi olarak; öğretmenler içerisinde kadın öğretmen sayısının erkek öğretmenlere nazaran daha fazla olması ve kadın öğretmenlerin mesleklerine karşı daha özenli oldukları söylenebilir.

Fen-Edebiyat Fakültesi mezunu SBÖ’ler Eğitim Fakültesi mezunu SBÖ’ye göre aktif öğretim yöntemlerini daha çok kullanmaktadırlar. Eğitim fakülteleri ülkemizin öğretmen ihtiyacını karşılayan eğitim kurumlarıdır. Eğitim fakültelerinden önce bu ihtiyacı fen-edebiyat fakülteleri karşılamaktaydı. Eğitim fakültesinde öğrenim gören öğretmen adayları öğretmenlik meslek derslerini daha yoğun ve uygulamalı şekilde almaktadırlar. Fen-edebiyat fakülte mezunları ise günümüzde "Pedagojik Formasyon Sertifika Programı" adı altında öğretmenlik mesleği belgesi almaktadırlar. Genel beklenti; eğitim fakültesi mezunu öğretmenlerin, öğretmenlik mesleğini Fen-Edebiyat veya farkl1 fakülte mezunlarından daha iyi yapmasıdır. Ancak bu araştırma sonucu; Eğitim Fakültesi mezunu SBÖ’ler, fen-edebiyat fakültesi mezunu SBÖ’ye nazaran daha çok öğretmen merkezli öğretim yöntem ve uygulamalarını kullandığını göstermektedir. $\mathrm{Bu}$ sonucun aksine farklı yıllarda yapılan bazı araştırmalarda öğretmenlerin kullandıkları öğretim yöntem ve tekniklerin mezun oldukları fakülteye göre farklılaşmadığı sonucuna ulaşılmıştır (Babadoğan, 1996; Saracaloğlu, Karasakaloğlu ve Gencel, 2011; Saraçaloğlu, Yenice ve Gencel, 2011).

Araştırmaya katılan SBÖ’nün öğrenim durumu değişkenine göre tercih ettikleri öğretim yöntem ve uygulamalarda anlamlı bir farklılık görülmemiştir. Ögretmenler kendilerini geliştirmek ve kariyer planlamalarında daha bir gelecek için meslekleri ile ilgili yüksek lisans eğitim almak istemektedirler. Genel olarak düşünüldüğünde yüksek lisans eğitim alan bir bireyin edindiği bilgi ve birikimi mesleğine daha fazla aktarması beklenirken, bu araştırmaya katılan ve lisansüstü eğitim alan SBÖ'nün bilgi ve birikimlerini mesleğine aktaramadıkları görülmektedir. Elde edilen bu sonucun aksine Aydemir (2012) araştırmasında; yüksek lisans mezunu SBÖ'nün problem çözme yöntemi ile öğretim yapabilme düzeylerinin lisans mezunu SBÖ’den daha yüksek olduğunu belirtmiştir.

Özel eğitim kurumlarında görev yapan SBÖ’ler devlet okullarında görev yapan SBÖ’ye nazaran aktif öğretim yöntemlerini daha çok kullanmaktadırlar. Türkiye'de özel eğitim kurumlarında öğretmenlik yapmak devlet kurumlarında öğretmenlik yapmaktan daha zordur. Sosyal haklar bakımından özel eğitim kurum öğretmenleri içinde bulundukları durumdan hoşnut olmayabilirler. Özel eğitim kurumlarının öğretmen istihdam ederken "kadrolu ögrretmen" anlayışı olmadığından öğretmenler daha verimli çalışmaktadırlar. Bu durum tartışılabilir. Ancak bu araştırma; özel eğitim kurumlarında çalışan SBÖ'nün devlet okullarında çalışan SBÖ'ye nazaran öğretim yöntem ve uygulamalarını daha etkili kullandıklarını göstermektedir.

Araştırmaya katılan SBÖ’nün tercih ettikleri öğretim yöntem ve uygulamaları mezun olunan alana göre değişmektedir. Ölçeğin puan ortalamalarına göre pasif öğrenme yöntemlerini, öğrenen merkezli uygulamaları ve bilişsel strateji öğretimini en fazla uygulayan Coğrafya bölümü mezunları, en az uygulayanlar sınıf öğretmenliği mezunu Sosyal Bilgiler öğretmenleridir. SBÖ mezunu olan öğretmenler öğrenen merkezli öğretim yöntemlerinden çok öğretmen merkezli pasif öğretim yöntem ve uygulamalarını kullanmaktadırlar. Diğer yandan araştırmaya katılan SBÖ bölge değişkeni fark etmeksizin öğretmen merkezli pasif öğretim yöntem ve uygulamalarını kullanmaktadırlar.

SBÖ’nün meslekî kıdem yılları arttıkça tercih ettikleri öğretim yöntem ve uygulama çeşitliliği de azalmaktadır. Ocak vd. (2012) ilköğretim öğretmenlerinin öğretim yöntem ve tekniklerine yönelik tutumlarının meslekî kıdeme göre değiştiğini özellikle 11-15 hizmet yılı olan öğretmenlerin öğretim yöntem ve teknik kullanımına yönelik tutum puanlarının diğer hizmet yılı gruplarına nazaran daha 
düşük olduğunu belirtmiştir. Öğretmenlik mesleğinde "Meslekî Tükenmişlik Sendromu” nun bu y1llarda daha belirgin bir şekilde hissedilmesi bu durumun sebebi olarak ifade edilebilir. Diğer yandan Aydemir' in (2012) araştırma sonuçlarına göre öğretmenlerin meslekî kıdemi arttıkça öğretim yöntem, teknik ve stratejileri kullanabilme yeterlik düzeyleri azalmaktadır. $\mathrm{Bu}$ araştırmaların aksine Saraçaloğlu, Yenice ve Gencel (2011) ve Kayabaşı (2012) öğretmenlerin kullandıkları öğretim yöntem ve tekniklerin meslekî kıdeme göre değişmediğini belirtmişlerdir. SBÖ'nün tercih ettikleri öğretim yöntem ve uygulamaları, öğretmenlerin haftalık ders saatlerine göre de anlamlı farklılaşmamaktadır. Araştırmaya katılan SBÖ'nün haftada girdiği ders saatinin az ya da çok olması tercih ettiği öğretim yöntem ve teknik üzerine etki etmemektedir. Ders yükü çok fazla olan öğretmenin farklı öğretim yöntem ve tekniği kullanması yoğunluktan dolayı beklenmeyebilir ancak ders yükü az olan öğretmenin derse hazırlık için zamanı olacağı düşünülmesinden böyle bir beklenti oluşabilir. İlgili alan yazın incelendiğinde öğretmenlerin haftalık ders yükü ve tercih ettiği öğretim yöntemleri arasında ilişkinin olduğu bir araştırmaya rastlanılmamıştır. Ancak bu araştırmanın sonuçları ile Saraçaloğlu, Yenice ve Gencel'in (2011) yaptıkları araştırma sonuçları paralellik göstermiştir.

Araştırmadan elde edilen bulgulardan hareketle öğretmenlerin kullandıkları/tercih ettikleri öğretim yöntem ve uygulamalarına ilişkin çeşitli önerilerde bulunulmuştur. Bu öneriler, öğretmenlere, kurumlara ve araştırmacılara öneriler olarak başlıklandırılmıştır. Bunlar;

\section{Öğretmenlere Yönelik Öneriler}

1. Akademik başarıdan çok beceri ve süreç odaklı öğrenme ortamları oluşturulması.

2. Öğrenenlerin her birini ayrı bir dünya kabul ederek, her birinin farklı bir şekilde öğrendiğini kabul etmek ve öğretim süreçlerini bu durumu gözeterek planlamak.

3. Öğretmenlerin kendi alanlarıla ilgili güncel eğitim gelişmelerini takip etmesi ve bu gelişmelerin uygun olanlarını kendi öğrenme ortamlarında uygulamaları.

\section{Kurumlara Yönelik Öneriler}

1. Öğrenen merkezli eğitim-öğretim için, öğrenen merkezli okullar veya öğrenme ortamları oluşturulması.

2. Öğretmenler, öğretme değil birlikte öğrenme ve öğrenmeyi öğretme süreçleri ile ilgili heyecanlarını artıracak öğrenme toplulukları ile tanıştırılması. (Öğretmen ağı, köy okulları değişim ağı, başka bir okul mümkün, alternatif eğitim vb.).

3. Öğretmenlik mesleğinde heyecanını ve ideallerini kaybetmiş öğretmenler için çeşitli çalışmalar yapılması. (Millî Eğitim Bakanlığı, Üniversiteler ve Sivil Toplum Kuruluşları vb.).

4. Öğretmen başına düşen öğrenen sayısının düşürülmesi.

\section{Araștırmacılara Yönelik Öneriler}

1. $\mathrm{Bu}$ araştırma Sosyal Bilgiler öğretmenleri ile yapılmıştır. Farklı branşlar ile ilgili araştırmaların da yapılması.

2. Öğretmenlerin derslerinde kullandığı yöntem ve teknikler üzerine nitel veya karma araştırmaların da yapılması.

3. Öğretmenlere yönelik, öğretim yöntem ve uygulamaları hakkında bilgi sahibi olacak ve uygulama imkanı bulacak çeşitli atölyelerin yapılması vb. öneriler getirilebilir.

Açıklama: Bu araştırma 19 - 22 Haziran 2019 tarihlerinde Ankara'da düzenlenen 6. Uluslararası Avrasya Eğitim Araştırmaları Kongresi'nde (EJER) sözlü bildiri olarak sunulmuştur.

\section{Kaynaklar}

Adıgüzel, A. (2011). Bilgi okuryazarlığı ölçeğinin geliştirilmesi. Dicle Üniversitesi Ziya Gökalp Eğitim Fakültesi Dergisi, 17, 15-28. 
Akçay, O, N., Akçay, A. ve Kurt, M. (2016). Ortaokul öğretmenlerinin öğretim yöntem ve tekniklerine yönelik görüş ve yeterliliklerin incelenmesi. Eğitim ve Öğretim Araştırmaları Dergisi, 5(1), 333-342.

Aksu, M. B., Çivitçi, A. ve Duy, B. (2008). Yükseköğretim öğrencilerinin öğretim elemanlarının ders uygulamaları ve sınıf içi davranışlarına ilişkin görüşleri. İnönü Üniversitesi Eğitim Fakültesi Dergisi, 9(16), 17-42.

Aşılığlu, B. ve Oral, B. (2000) Lise Türk Dili ve Edebiyatı dersi öğretmenlerinin Türk dili ve programı hakkındaki görüşlerinin değerlendirilmesi. Eğitim ve Bilim Dergisi, 25(116), 34-41.

Aydemir, H. (2012). Sosyal Bilgiler öğretmenlerinin öğretim yöntem, teknik ve stratejileri kullanma yeterlikleri. Hikmet Yurdu Dergisi, 5(9), 81-100.

Aykaç, N. (2011). Hayat Bilgisi dersi öğretim programında kullanılan yöntem ve tekniklerin öğretmen görüşlerine göre değerlendirilmesi (Sinop ili örneği). Kastamonu Eğitim Dergisi, 19(1), 113126.

Avcı, E. K. ve Kayabaşı, Z. E. K. (2018). Hayat Bilgisi dersi öğretim programlarının amaçlarındaki değerlerin içerik analizi (1936-2018). Değerler Eğitimi Dergisi, 16(35), 27-56.

Babadoğan, C. (1996). Öğretmenlerin kuralcı öğretim stratejilerini kullanma düzeyleri. III. Ulusal Eğitim Bilimleri Kongresi, Uludağ Üniversitesi, Bursa. http://babadogan.net/wpcontent/PDF/C3.pdf [Erişim Tarihi: 18.08.2019].

Balc1, A. (2015). Sosyal bilimlerde araştırma yöntemleri: Yöntem, teknik ve ilkeler. Ankara: Pegem A Yayıncilik.

Binler, A. İ. (2007). Fen öğretmenlerinin öğretim yöntem ve tekniklerini kullanma yatkınlıklarl. (Yayınlanmamış Yüksek Lisans Tezi). Kafkas Üniversitesi, Fen Bilimleri Enstitüsü, Kars. (Tez No: 179372).

Borich, G. D. (2011). Effective teaching methods: Research-based practice. Pearson Education, India.

Bulut, G. (2010). Illkögrretim (6-7-8. Sinıf) Fen ve Teknoloji öğretmenlerinin ögrretim yöntem ve tekniklerini kullanma alışkanlıkları: Hatay İli Örneği. (Yayınlanmamış Yüksek Lisans Tezi). Firat Üniversitesi, Fen Bilimleri Enstitüsü, Elazığ. (Tez No: 259177).

Burke, L. (2012). Reading practices in social studies classrooms: Teacher support for middle-school students with ASC (Unpublished Ph.D. dissertation). Northern Illinois University. http://www.indigo.lib.uic.edu:8080/bitstream/handle/10027/8644/Burke_Lisa.pdf?sequence=1\& isAllowed=y [Erişim Tarihi: 12.06.2019].

Büyüköztürk, Ş., Çakmak, K. E., Akgün, E. Ö., Karadeniz, Ş. ve Demirel, F. (2018). Eğitimde bilimsel araştırma yöntemleri. Ankara: Pegem A Yayıncılık.

Can, G., Yaşar, Ş. ve Sözer, E. (1998). Sosyal Bilgiler öğretimi. Eskişehir: Anadolu Üniversitesi Yayınları.

Christensen, L. B., Johnson, R. B. and Turner, L. A. (2014). Research methods design and analysis. Pearson Education, Inc.

Cohen, L., Manion, L. and Morrison, K. (2007). Research methods in education. (6th Ed.). New York, US: Routledge/Taylor \& Francis Group. 
Covill, A. E. (2011). College students perceptions of the traditional lecture method. College Student Journal, 45(1), 2-15.

Çelikkaya, T. ve Kuş, Z. (2009). Sosyal Bilgiler öğretmenlerinin kullandıkları yöntem ve teknikler. Uludağ Üniversitesi Ĕ̈itim Fakültesi Dergisi, 22(2), 741-758.

Davis Langston, C. (2012). Exploring relationships among teaching styles, teachers' perceptions of their self-efficacy, and students' mathematics achievement. (Doctoral Dissertation). Liberty University.

Demir, S. ve Özden, S. (2013). Sınıf öğretmenlerinin öğretimsel stratejilere yöntemlere ve tekniklere ilişkin görüşleri: Hayat bilgisi dersine yönelik tanılayıcı bir çalışma. Pamukkale Üniversitesi Sosyal Bilimler Enstitüsü Dergisi, 14, 59-75.

Demirel, Ö. (2007). Kuramdan uygulamaya eğitimde program geliştirme. Ankara: Pegem A Yayınclık.

Demircioğlu, İ. H., Genç, İ. ve Demircioğlu, E., (2015). Sosyal Bilgiler öğretmen adaylarının öğretim strateji, yöntem ve teknikleriyle ilgili bilgi düzeylerinin değerlendirilmesi. Abant İzzet Baysal Üniversitesi Eğitim Fakültesi Dergisi, 15(USBES Özel Sayısı I), 18-34.

Demirezen, S. (2001). Öğretmenlerinin ögrretim stratejileri ile ögrretim yöntem ve tekniklerine ilişkin görüşleri. [Yayınlanmamış Yüksek Lisans Tezi]. Hacettepe Üniversitesi, Sosyal Bilimler Enstitüsü. Ankara. (Tez No: 100421).

Doğru, M. ve Aydoğdu, M. (2003). Fen Bilgisi öğretiminde kullanılan yöntemlerde karşılaşılan sorunlar ile ilgili öğrenci görüşleri. Pamukkale Üniversitesi Eğitim Fakültesi Dergisi, 1(13), 150-158.

Duman, E., Z. (2008). Ortaöğretimde ögrretimde öğretim ilke, yöntem ve teknikler açısından mantık ögretimi. [Yayınlanmamış Yüksek Lisans Tezi]. Gazi Üniversitesi, Eğitim Bilimleri Enstitüsü. Ankara.

Erdem, A. ve Bayraktar, A. (2019). Öğretmen adaylarının Türkçe öğretimi uygulamalarına ilişkin görüşleri. Ana Dili Ĕgitimi Dergisi, 7(1), 11-27.

Eroğlu, G. (2007). Mesleki ve teknik eğitim fakültelerinde kullanılan ögrenme ve öğretme stratejilerinin incelenmesi. [Yayınlanmamış Doktora Tezi]. Gazi Üniversitesi, Eğitim Bilimleri Enstitüsü. Ankara. (Tez No: 206942).

Eskici, M. ve Çetinkaya, S. (2019). Öğretmenlerin öğretim stillerinin çeşitli değişkenler açısından incelenmesi. Bartın Üniversitesi Ĕ̈itim Fakültesi Dergisi, 8(1), 138-160.

Faruji, L. F. (2012). Teachers' teaching styles at English Language institutes in Iran. International Journal of Social Sciences and Education, 2(1), 364-373.

Fraenkel, J. R., Wallen, N. E. and Hyun, H. H. (2012). How to design and evaluate research in education. (Eighth edition). McGraw-Hill, New York.

Grasha, F. A. (1994). A matter of style: The teacher as expert, formal authority, personal model, facilitator, delegator. College Teaching, 42(4), 12-20.

Gözütok, D. (2006). Öğretim ilke ve yöntemleri. Ankara: Ekinoks Yayınc1lık.

İlter, İ. (2018). Öğretmenlerin Sosyal Bilgiler derslerinde öğretim yöntemleri ve uygulamaları üzerine bir değerlendirme. Kuramsal Eğitimbilim Dergisi, 11(1), 1-29. 
Jungst, S., Licklider, L.L. and Wiersema, J. (2003). Providing support for faculty who wish to shift to a learning-centered paradigm in their higher education classrooms. The Journal of Scholarship of Teaching and Learning, 3(3), 69-81.

Kaya, E. ve Harurluoğlu, Y. (2007). Öğrencilerin gözüyle biyoloji öğretim elemanlarının kullandıkları öğretim yöntemleri. Çankaya Üniversitesi Fen-Edebiyat Fakültesi Dergisi, 8, 35-49.

Kayabaşı, Y. (2012). Öğretmenlerin öğretim sürecinde kullandıkları öğretim yöntem ve teknikleri ile bunları tercih etme nedenleri. Balıkesir Üniversitesi Sosyal Bilimler Enstitüsü Dergisi, 15(27), $45-65$.

Klein, B.S., Matkins, J.J. and Weaver, S.D. (1999). Initiation of a collaborative approach for elementary science methods courses: Teaching across collaborative highways (TEACH). Electronic Journal of Science Education, 4(1).

Koç, İ. (2013). Öğretmenlerin Sosyal Bilgiler dersinde drama yöntemini uygulama ve drama tekniklerine ilişkin yeterliliklerinin belirlenmesi. Ahi Evran Üniversitesi, Sosyal Bilimler Enstitüsü. (Yayınlanmamış Yüksek Lisans Tezi). Kırşehir. (Tez no: 348890).

Küçükoğlu, A. ve Kaya, H. İ. (2007). Öğretim hizmetinin niteliğini artırmada ögretmen yeterlilikleri. (Ed.: A. S. Saracaloğlu ve Bahar, H. H.). Öğretim İlke ve Yöntemleri. İstanbul: Lisans Yayinc1lik.

Marbach-Ad, G., Seal, O. and Sokolove, P. (2001). Student attitudes and recommendations on active learning. Journal of College Science Teaching, JO, 434-438.

Martinez, F. J. (2003). Learning and teaching styles of theory of flight students ed.d. Oklahoma State University. Proquest-Dissertation Abstract. AAT 3094065. s: 1-2.

Marzano, R. J., Pickering, D. and Pollock, J. E. (2001). Classroom instruction that works: Researchbased strategies for increasing student achievement. ASCD.

McCombs, B. L. and Miller, L. (2007). Learner-centered classroom practices and assessments: Maximizing student motivation, learning, and achievement. Thousand Oaks, CA: Corwin Press.

McMillan, H. J. and Schumacher, S. (2006). Research in education evidence-based inquiry. (6th Ed.), Boston: Allyn and Bacon Inc.

Millî Eğitim Bakanlığı. (2005). İlköğretim Sosyal Bilgiler dersi öğretim programı ve kılavuzu (6-7. Sınıflar). Ankara: MEB Talim ve Terbiye Kurulu Başkanlığı.

Millî Eğitim Bakanlığı. (2017). Hayat bilgisi dersi öğretim programı (İlkokul 1, 2 ve 3. Sinıflar). Ankara. http://ttkb.meb.gov.tr/www/ogretim-programlari/icerik/72, [Erişim tarihi: 11.03.2019].

Mendoza, S. (2008). Teaching styles of technological institutes faculty in El Salvador. Doctoral Dissertational. Capella University. A Dissertation Presented in Partial Fulfillment of the Requirements Capella University for the Degree Doctor of Philosophy: El Salvador. UMI Number: 3127201.

Taşkaya, S. M. ve Muşta, M. C. (2008). Sınıf öğretmenlerinin Türkçe öğretim yöntemlerine ilişkin görüşleri. Elektronik Sosyal Bilimler Dergisi, 7(25), 240-251.

National Council for the Social Studies. (2004). Program standards for the initial preparation of social studies teachers. Washington, DC: National Council for the Social Studies. 
Neuman, L, W. (2004). Social research methods: Qualitative and quantitative approaches. (7th Ed.). London: Pearson Education Limited.

Ocak, G. (2007). Yöntem ve teknikler. G. Ocak (Ed.) Öğretim ilke ve yöntemleri içinde (s. 213-282). Ankara: PegemA Yayıncılık.

Ocak, G., Ocak, İ., Yılmaz, M. ve Mergen H. H. (2012). İlköğretim öğretmenlerinin öğretim yöntem ve tekniklerine yönelik tutumları (Afyonkarahisar Örneği). İlkögrretim Online, 11(2), 504,519.

Oh, P. S. and Kim, K. S. (2013). Pedagogical transformations of science content knowledge in Korean elementary classrooms. International Journal of Science Education, 35(9), 1590-1624.

Önen, F., Saka, M., Erdem, A., Uzala, G. ve Gürdal, A. (2008). HİE seminerine katılan Fen Bilgisi öğretmenlerinin öğretim tekniklerine ilişkin bilgilerindeki değişimin tespiti: Tekirdağ örneği. Ahi Evran Üniversitesi Kırşehir Eğitim Fakültesi Dergisi (KEFAD), 9(1), 45-57.

Öztürk, Ç. (2004). Ortaöğretim coğrafya öğretmenlerinin öğretim yöntem ve teknikleri kullanabilme yeterlilikleri. Gazi Üniversitesi Ĕ̈itim Fakültesi, 5(2).

Sakallı, M., Hürsen, Ç. ve Özçınar, Z. (2006). Öğretmen adaylarının gözlemlerine göre öğretmenlerin ögretim yöntemlerini kullanma siklıkları. 6th International Educational Technology Conference: KKTC, Doğu Akdeniz Üniversitesi.

Saracaloğlu, A. S., Karasakaloğlu, N. ve Gencel, İ. E. (2011). Türkçe öğretmenlerinin tercih ettikleri öğretme stratejileri. e-Journal of New World Sciences Academy, 6(4), 2425-2435.

Saracaloğlu, A. S., Yenice, N. ve Gencel, İ. E. (2011). Fen Bilgisi öğretmenlerinin tercih ettikleri öğretme stratejilerinin çeşitli değişkenler açısından incelenmesi. Adnan Menderes Üniversitesi Eğitim Fakültesi Eğitim Bilimleri Dergisi, 2(2), 63-76.

Sarıslan, Y. (2005). Sosyal Bilgiler ögrretiminde sinıf ögrretmenlerinin öğretim yöntemleri ile ilgili bilgi ve becerilerini uygulama durumlart. Gazi Üniversitesi, Eğitim Bilimleri Enstitüsü (Yayınlanmamış Yüksek Lisans Tezi). Ankara. (Tez No: 159016).

Savage, T. V. and Armstrong, D. (1996). Effective teaching in elementary social studies. New Jersey: Prentice-Hall.

Silver, H. F. and Hanson, J. R. (1996). Understanding myself as a teacher. Learning Styles \& Strategies. Trenton: The Thoughtful Education Press, 77-107.

Skutil, M., Haclickova, K. and Matejickova, R. (2016). Teaching methods in primary education from the teacher's point of view. SHS Web of Conferences, 1-7.

Soylu, Y. (2009). Sınıf öğretmen adaylarının Matematik derslerinde öğretim yöntem ve teknikleri kullanabilme konusundaki yeterlilikleri üzerine bir çalışma. Mersin Üniversitesi Eğitim Fakültesi Dergisi, 5(1), 1-16.

Sunal, C. S. and Haas, M. E. (2012). Social studies for elementary and middle grades a constructivist approach (2th Edition). Allyn and Bacon, Pearson Education.

Sutton, S. E. (2003). A study of elementary school teachers' perceptions regarding the match between teachers' teaching styles and students' learning styles. [Doctoral Dissertational]. Seton Hall University.

Tan, Ş. (2005). Öğretimi planlama ve değerlendirme. Ankara: Pegem A Yayıncıllk. 
Yıldırım, E., G., Köklükaya, A., N. ve Aydoğdu, M. (2016). Fen Bilgisi öğretmen adaylarının öğretim yöntem- teknik tercihleri ve bu tercihlerinin nedenleri. e-Kafkas Eğitim Araştırmaları Dergisi, $3(1), 15-25$. 


\section{Extended Abstract}

\section{Introduction}

This research differs from many studies conducted so far in terms of sample size and variables. In this study; social studies working in Turkey, public and private educational institutions teachers teaching methods and practices were examined and evaluated. For this purpose, the following questions were sought;

1. What teaching methods and practices do social studies teachers use?

2. 2. Do the teaching methods and practices used by social studies teachers show significant differences according to gender, faculty, education level, type of school, field of graduation, region, service year and weekly course load?

\section{Method}

In this research, survey method, one of the quantitative research methods, was used to determine and evaluate the preferred teaching methods and practices of social studies teachers in their courses. The universe in the 2018-2019 academic year in 'Turkey Coterie of Social Studies' is 21.892 social studies teachers who are members of the Facebook group as of March 2019. 631 social studies teachers voluntarily filled the data collection tool of the research. The data collection tools of the research are 'Personal Information Form' in order to learn the information of social studies teachers and Likert type 'Social Studies Teaching Methods and Practices' scale developed by IIlter (2018). The scale, to be filled by social studies teachers 'Turkey Coterie of Social Studies' has helped the Facebook group manager. In this study, Cronbach Alpha value of the scale was 0.92 . the construct validity value of KMO was 0.941. Kolmogorov Smirnov test was used to determine whether the dependent variables showed normal distribution. ['Social Studies Teaching Methods and Practices' Kurtosis and skewness values were also examined to determine whether the data showed normal distribution. scale K-S (z) = 3.698; p: 0.05]. Descriptive statistics (e.g., frequency, percentage, mean), reliability analysis, t-test, one-way variance (ANOVA), LSD test were used. Jamovi 1.0.6 and SPSS 25.00 statistical program was used.

\section{Results, Discussion, and Recommendations}

Significant differences obtained from the research are as follows; social studies teachers mostly use 'Passive Learning Methods öğretim in their teaching methods and practices. Teachers focus primarily on teaching methods, techniques and strategies in which they are at the center and tend to stay away from student-centered methods, techniques and strategies (Grasha, 1994; Martinez, 2003; Mendoza, 2004; Marbach, Seal \& Sokolove 2001; Junst, Licklider \& Wiersema, 2003; Covill, 2011; Faruji, 2012; Oh \& Kim, 2013). According to the researches (Önen, Saka, Erdem, Uzal \& Gürdal, 2008), it was observed that teachers in different branches preferred methods-techniques and strategies that centered the teacher since they did not have sufficient knowledge and skills related to teaching methods-techniques and strategies in their courses. Among the most widely used teaching methods among teachers, there are straight narration and question and answer methods which are described as boring and ineffective methods (Klein, Matkins \& Weaver, 1999). Female social studies teachers used active learning methods such as 'Student-Centered Practices' and 'Cognitive Strategy Teaching katıl more than male social studies teachers. Social studies teachers graduated from Faculty of Arts and Sciences use active teaching methods more than social studies teachers graduated from Faculty of Education. Contrary to this result, in some researches conducted in different years, it was concluded that the teaching methods and techniques used by teachers did not differ according to the faculty they graduated from (Babadogan, 1996; Saracaloglu, Karasakaloglu \& Gencel, 2011; Saracaloglu, Yenice \& Gencel, 2011). There was no significant difference in the teaching methods and practices preferred by the social studies teachers according to the educational status variable. Social studies teachers working in special schools use active teaching methods more than social studies teachers working in public schools. The preferred teaching methods and practices of the social studies teachers 
participating in the research vary according to the field of graduation. Teachers who are graduates of social studies teachers use teacher-centered passive teaching methods and applications rather than student-centered teaching methods. As the service year of social studies teachers increases, the diversity of teaching methods and practices they prefer decreases. Ocak, Ocak, Yilmaz, and Mergen (2012) stated that the attitudes of primary school teachers towards teaching methods and techniques vary according to the service year, especially the attitude scores of teachers with 11-15 service years compared to the other service year groups. The preferred teaching methods and practices of social studies teachers do not differ significantly according to teachers' weekly lesson hours. The fact that the social studies teacher who participated in the study have more or fewer hours per week does not affect the preferred teaching methods and techniques. Based on the findings of the research, various suggestions were made regarding the teaching methods and practices that teachers used/preferred. These recommendations are titled as suggestions to teachers, institutions, and researchers. These;

\section{Suggestions for Teachers;}

1. Creating skills and process-oriented learning environments rather than academic achievement.

2. Accepting each of the students as a separate world, acknowledging that each student has learned differently, and planning their teaching processes with this in mind.

3. Teachers to follow current educational developments in their fields and apply these developments in their learning environments.

\section{Recommendations for Institutions;}

1. Establish student-centered schools or learning environments for student-centered education.

2. Introducing teachers to learning communities that will increase their enthusiasm for the process of learning and teaching learning together, not teaching. (Teacher network, village school exchange network, another school possible, alternative education, etc.).

3. Conducting various studies for teachers who have lost their enthusiasm and ideals in the teaching profession. Ministry of National Education, Universities and Civil Society Organizations.

4. Reducing the number of students per teacher

\section{Suggestions for Researchers;}

1. This research was conducted with social studies teachers. Conducting researches on different branches.

2. Conducting qualitative or mixed research on the methods and techniques used by teachers in their courses.

3. Conducting various workshops for teachers, which will have information about teaching methods and practices and will have the opportunity to practice etc. suggestions can be brought. 